\title{
Geestelijke gezondheidkunde : notities
}

Citation for published version (APA):

van den Hout, M. A. (1988). Geestelijke gezondheidkunde : notities. Rijksuniversiteit Limburg. https://doi.org/10.26481/spe.19881028mh

Document status and date:

Published: 28/10/1988

DOI:

10.26481/spe.19881028mh

Document Version:

Publisher's PDF, also known as Version of record

\section{Please check the document version of this publication:}

- A submitted manuscript is the version of the article upon submission and before peer-review. There can be important differences between the submitted version and the official published version of record.

People interested in the research are advised to contact the author for the final version of the publication, or visit the DOI to the publisher's website.

- The final author version and the galley proof are versions of the publication after peer review.

- The final published version features the final layout of the paper including the volume, issue and page numbers.

Link to publication

\footnotetext{
General rights rights.

- You may freely distribute the URL identifying the publication in the public portal. please follow below link for the End User Agreement:

www.umlib.nl/taverne-license

Take down policy

If you believe that this document breaches copyright please contact us at:

repository@maastrichtuniversity.nl

providing details and we will investigate your claim.
}

Copyright and moral rights for the publications made accessible in the public portal are retained by the authors and/or other copyright owners and it is a condition of accessing publications that users recognise and abide by the legal requirements associated with these

- Users may download and print one copy of any publication from the public portal for the purpose of private study or research.

- You may not further distribute the material or use it for any profit-making activity or commercial gain

If the publication is distributed under the terms of Article $25 \mathrm{fa}$ of the Dutch Copyright Act, indicated by the "Taverne" license above, 


\section{Geestelijke \\ Gezondheidkunde}

Notities

Rede uitgesproken bij de aanvaarding van het ambt van gewoon hoogleraar in de Geestelijke Gezondheidkunde aan de Rilksuniversiteit Limburg te Maastricht op 28 oktober 1988 door Prof. Dr. Marcel A. van den Hout. 

Dames en Heren.

De leerstoel die met het uitspreken van deze rede wordt aanvaard werd Geestellike Gezondheidkunde genoemd. De leerstoel is nieuw; niet eerder werd in Nederland zo in leeropdracht verleend en graag grijp ik deze gelegenheld aan om de aard van het nieuwe vakgebied enigszins te preciseren.

Allereerst zal de vraag aan de orde komen waar Geestellike Gezondheidkunde over góát. Wat is het object van deze discipline? Vervolgens zal nader worden ulteengezet hoe de Geestelljke Gezondheidkunde kan bijdragen aan het wetenschappelijk onderzoek. Tot slot zullen besplegelingen worden gegeven omtrent de maatschappelijk relevantie van Geestellike Gezondheldkunde, het onderwils in de Geestelijke Gezondheldkunde en de verhouding van de oplelding Geestelljke Gezondheidkunde met reeds bestaande opleidingen.

Waar gáát Geestelijke Gezondheidkunde over?

Om te beginnen moet hier gewezen worden op een misverstand dat snel ontstaat en dat in de klem gesmoord dient te worden. Het misverstand is dat er zolets bestaat als wetenschappellike kennis over wat geestellike gezondheld is. Meer in het bilzonder luldt het misverstand dat sommige universitair geschoolden over kennis beschikken omtrent de aard van gezonde geesten en dat zulke deskundlgen hun inzicht kunnen overdragen aan studenten.

Welnu, lk weet nlet wat geestelijke gezondheld is. Verdenkt $U$ mil nletvan valse bescheidenheld, het is om princliplële redenen 
dat ikmeen dater, althans vanuit wetenschappelijk standpunt. nlet veet verstandigs te zeggen is over wat geestelijke gezondheid constitueert.

Laat ons allereerst stilstaan bij de notie "gezondheld". Het omschrliven van wat gezondheld is, is een helkele onderneming. Onder de filosofen van onze facultelt bevinden zich voortreffellike geleerden die hierover verstandiger kunnen spreken dan Ik, doch ik ontkom er niet aan althans enige opmerkingen over het begrip te maken. In het dagelijks spraakgebruik slaat gezondheid op het "juist" of "optimaal" functioneren van het organisme c.q. van delen ervan. Als organismen hun mogelijkheden tot groel en ontwikkeling zo ontploolen, dat hun integriteit en levensduur optimaal wordt gewaarborgd, dan spreken we doorgaansvan "gezondheid" . Het is verleidelijk zo'n ldee van gezondheid als "julst functioneren", als "optimale ontplooiing" ook toe te passen op mensellik gedragen mentale processen. Zo'ngenerallsatie is ook niet ongebruikelijk. Zo verklaart de Wereldgezondheidsorganlsatie op 22 Jull 1946 dat gezondheid is "de toestand van volledlg fyslek. mentaal en sociaal welbevinden en nlet louter de afwezigheld van zlekte of gebrek". Om gezond te zjjn moet men zich mentaal volledig welbevinden. A propos, het kan nlet anders dan dat de WHO hler méer mee bedoelt dan dat de betrokkene zich slechts "subjectief" valledig mentaal welbevindt: men denke aan het intense subjectieve welbevinden dat alcohol of oplaten kunnen oproepen. Alcoholische euforie kan men kwalijk prototypisch gezond noemen. Nee, ook de WHO Impliceert met "volledig mentaal welbevinden" een objectlef optimad functioneren. Als gezondheld verwijst naar optimaal functioneren van het organisme, danzou Geestelijke Gezondheld slaan op optimaal 
mentaal of gedragsmatig functioneren. Wat is er tegen die gedachte?

Allereerst wil het geval dat het aantal dingen dat we in principe kumnen doen, het aantal sentimenten dat we kunnen voelen en het aantal gedachten dat we kunnen hebben vrijwel onbeperkt is. Wat we feitelijk denken, voelen of doen, is slechts een minuscule selectie wit een onafzlenbaar aantal alternatieven. Indien we het universum van potentleel doen. voelen en denken voor een individu nlet ultputtend kunnen omschrljven, weten we ook niet of een bepaalde selectle van gedragingen "optimaal" is.

Belangrijker nog komt mil het volgende voor. Al doende en al latende, streven mensen doelen na. Dát mensen doelen stellen, hóe ze dat doen, waárom ze dat doen, dat zljin empirische kwesties. Of hetechter psychisch gezond, in de zin van "optimaal" is om bepaalde doelen wel na te streven en andere nlet. dat is geen emplrische, maar een normatieve zaak. Het gaat er daarbil om welke doelen wel of net waard zilin om na te streven en het gaat er daarbil om hoe mensen behorente handelen. Dit "behoren" is nochonderdeel van de gedragswetenschap, noch vangezondheldswetenschappen, nach van enig andere empirische wetenschap. Zaals door zovelen beargumenteerd, ziln er geen logische of emplrische argumenten op basis waarvan uiteindelik besloten kan worden weke doelen nagestreefd zouden moeten worden. Wie bepaalde doelen als "optimaal " propageert, die morallseent. Wie zich daarbil beroept op deempirische wetenschap, pleegt boerenbedrog. Hil verkoopt knollen voor citroenen.

Kort samengevat: gezondheld verwilst naar optimaal functioneren van het organisme. Er zilin twee redenen waarom optimaal "geestelijke" functioneren nlet éénduidig is te 
definieren. In de eerste plaats is er een kwantitatief probleem: wil kennen niel alle wijzen waarop mensen geestelikk kunnen functioneren en bijgevolg weten we nooll of bepaalde mentale processen of gedragingen "optimaal" zijn. In de tweede plaats zijn bll het ldee van optimaal geestelijk functioneren morele premissen in het geding. Over de geldigheid vandie premissen valt langs wetenschappelike weg niets te zeggen.

Ik ontikwam er niet aan U te melden dat ik geen benul heb wat geestelike gezondheld ls. Met deze mededeling echter is de kous nlet af. U zult dat vermoedelijk hebben afgeleid uil het felt dat de oratie slechts enkele minuten heeft geduurd terwill U een openbare les van veel langer in het voorultzlcht was gestelld. Laat ons vervolgen. Het komt mill, zoals gezegd, voor dat geestelikke gezondheid zich niet laat definiêren. Daaruit volgt niet dat de empirische wetenschap de geestelijke gezondheldszorg links moet laten liggen. Mil lijkt dat de bemoelenis van de wetenschap met de geestelijke gezondheidszorg indirect is. Dit verdient toellchting.

zojulst' ging het over heerlikkheden zoals het volledige mentale welbevinden van de WHO. Nu zou lk de bllk willen richten op het omgekeerde van zulke paradijselijke notles. Ik zou willen stilstaan blj kommeren kwel: blj verdrieten ellende. Mijmerend hierover maakte Freud een brulkbaar en ontnuchterend onderscheld tussen "echte" en "neurottsche" ellende. Echte ellende kennen we maar al te goed en dat zal wel zo bliven ook: er is geen reden te verwachten dat we op het ondermaanse bevrlja zullen worden van eenzaamheld, piln. zlekte en dood. Echte ellende is ellende die onlosmakellkk verbonden is met de condition humaine. Andersllgt datbll wat Freud noemde "neurotische" ellende en wat hiler zonder bezwaar verbreed kan worden tot psychopathologische 
ellende. Voorbeelden zilin het horen van stemmen die er niet zilin, het voelen van heftige pijn zonder dat letsel aanwijsbaar is, het onvermogen het huis te verlaten uit angst voor een dreiging die er nlet is enzovoorts. (Terzj) de zil gememoreerd dat in veel gevallen de term "psychopathologle" als metafoor moet worden begrepen, ongeveer zoals men ook een staatshuishouding als ziek kan betitelen. Dat neemt niet weg dat de term psychopathologle vaak een bruikbare beeldspraak is. Deze kwestie laat ik rusten). Kenmerkend voor psychopathologische ellende ten opzichte van "echte" ellende is natuurlijk niet dat psychopathologie "onecht" is of dat de lijdensdruk gering is. Integendeel, het verdriet en de invalldering ten gevolge van psychopathologische problemen kunnen hartverscheurend zilin.

Kenmerkend voor psychopathologische ellende ten opzlchte van "echte" ellende lijkt veeleer dat de narigheid waaronder betrokkene lijdt naar gebruikelijke maatstaven niet onvermijdelijk is. c.q. niet rationeel is. Opvallend is dat één en ander niet wordt opgelost door zakelljke informatie te verstrekken: de mededeling dat spinnen ongevaarlijk zlin doet spinnenvrees niet verdwijinen, de mededeling dat er geen geluidsgolven trilden toen de paranödlcus een stem hoorde. zall miet lelden tot verdwilnen van de paranola. Van huidig belang is vooral dat psychopathologlsche processen mensen hinderen om hun leven op een voor hen bevredigende wijze in te richten. Neurotische angsten, depressies, wanen e.d. ontnemen mensen de mogellikheld te werken, llef te hebben of te spelen.

Terugdenkend aan wat zojuist werd gezegd over gezondheid ais optimale ontplooiling of volledig welbevinden, vallen asymmetrieen in het oog. Terwill we, zoals betoogd, noolt 
weten of met bepaald gedrag een individu zich "optimaal" ontploolt, is het weilmogelik blokkadesaan te geven waardoor ontplooling, welbewinden etc. bepent wordt. Neurotische angsten. psychotische wanen, obsesslef ritualiseren zijn vril eenvoudig als zodanig te identiflceren en vormen emstige belemmeringen voor de vrije ontwikkeling van de betrokkenen. "Optimaal" functioneren valt niet te ldentificeren; sub-optimaal functioneren ten gevolge van psychopathologisch lijden valt wi te lokalseren.

Een tweede asymmetrie heeft betrekking op de genoemde onmogelijkheid om "behoren" uit "zijn" te deduceren. Wanneer we niet proberen om volledig geestelijk welbevinden, te beschrijven of te realiseren maar alswe, bescheidener, trachten geestelljke ongezondheld te identificeren en te reduceren. dan ls zedenmeesteril beter te vermilden. Bil de omschrijuing of behandeling van psychopathologie hoeft de wetenschapper zich nlet ult te spreken over hoe de ander ziln leven in moet richten. Interventies kunnen dienen om de betrokkene in staat te stellen om, ongehinderd door Irresle angsten, depressies, wonen etc. zjjn leven zo in te rlchten zoals hilj dat goeddunkt.

Wat ons bezig hield was de mogelijkheid van wetenschappelijke bemoelenismet degeestelike volksgezondheld. Ditonderwerp kannuenigszins wordenverduldelijkt. Langs wetenschappellike weg kangeestelijke gezondheid noch ondubbelzinnig worden gedefinieerd, noch rechtstreeks worden nagestreefd. Wel echter kan geconstateerd worden dat sommige mensen ernstlg geblokkeerd raken in hun vermogen zlch te on tploolen. De psychopathologische nosologle geeft een staalkaart van dergelilke gemankeerde ontploollng. Voor zover de wetenschap de geestelijke gezondheid kan bevorderen. 
gebeurt dat indirect; nlet door het bevorderen van welzijn. doch door het reduceren van psychopathologie.

In het voorgaande verwees ik naar de WHO-definitie van gezondheid als, onder meer, volledig mentaal welbevinden. Dle canduiding roept associaties op met de hemel op darde en de omschrilving leek daardoor naïef, zo niet hilarisch. Bil nadere inspectie echter is die aanduiding misschienzo dwaas nog niet. Misschlen moet volledig welbevinden simpelweg begrepen worden als ideaal waarvan we op voorhand weten dat we het niet kunnen kennen en noolt zullen bereiken doch dat desondanks nagestreefd kan worden. Immers, al kennen we het ideaal nlet, over de belemmeringen bij de reallsering ervan weten we wel iets en aan die belemmeringen kunnen we wellicht lets doen. Geldt er niet lets vergelijkbaars voor ons wetenschappelijk onderzoek? Ook daar is de rationale dat we een ideaal, nll. het ideaal van volledige kennis, bereiken terwijl we er zeker van zilin de ultieme waarheid nooit te zullen kennen. Wel echter kunnen we onhoudbare theorleen als zodanig ontmaskeren en elimineren. Net zoals we de kennls vanhetWezender Dingennooltzullen bereikenen de warheld enkel lets dichterbil brengen door de eliminatle van onwaarheld, zo kunnen we het onberelkbare "volledige welbevinden" wellicht lets minder ver brengen door reduktle van overbodig lliden.

Zo zilin we aangekomen bil wat ik gaarne beschouw als het geëigende object van deze nleuwe wetenschappelijke tak van sport, de geestelijke gezondheidkunde. Het vak is geen salutaire onderneming: het is geen welzinnswetenschap. Het vak bestrijkt irrationeel gedrag dat de betrokkene doet lijden. Door onderzoek dient nagegaan te worden welke mechanismen ten grondslag liggen aan gestoord gedrag. In 
klinisch werk dient, wadr mogelijk, het verkregen inzicht te worden toegepast. in het onderwils moeten studenten vertrouwd worden gemaakt met de stand van wetenschap en de magellikheden deze toe te passen.

Graag ga ik lets dieper in op de bljdragle die Geestelike Gezandheidkunde kan leveren aan het wetenschappelilk onderzoek. Ik zou dat willen doen door $U$ een casus voor te leggen. Het betreft geen gevalsbeschrijving van een patlënt. maar de casus betreft de stand van zaken op één onderzoeksgebled, te weten het onderzoek maar paniekstaornissen. Onderzoek naar panlek vormt éen, en slechts eén van de onderzoeksthema's van de vakgroep Geestelike Gezondheldkunde.

Kenmerkend voor de panlekstoornis is het optreden van paniekaanvallen: episodes van plotselinge heftlge angst waarbil betrokkene vreest dood te gaan, flauw te vallen. krankzinnig te worden of dat andere rampen zich elk moment zullen voltrekken. De aanvallen gaan gepaard met o.m. duizeligheld, hartklopplingen, trillerigheld, wazig zien, vlagen van warmte. Bij sommigen treden de aanvallen alleen op wanneer betrokkenen zich in specifleke situatles bevinden. Dlkwills echter ziln de aanvallen niet situatlef. De panlek slaat plots, onvoorspeld toe. Er is weinig voor nodig om in te zlen hoezeer het levensplezler vergald kan worden door de permanente drelging van een nleuwe eplsode van radeloze angst. Begrijpelijkerwiljs ontwikkelen veel patienten een "anticlpatieangst", ze zijn bang dat een nleuwe aanval optreedt. Onderzoekskwestles liggen voor de hand. Hoe kómt het dat sommige mensen paniekaanvallen hebben en. natuurlikk. wat is daaraan te doen? 
Welnu, verklaringen van de panlekstoomis bliken op verschillende nivo"s gegeven te kunnen worden. Een losse greep uit de recente bevindingen moge een indruk geven. Met kracht worden de laatste Jaren biologische verklaringen van de paniekstoornls naar voren gebracht. Er zijin dan ook enkele gegevens die de vruchtbaarheld van biologische perspectleven steunen: zo is de kans dat een 2 de lld van een tweeling panlekstoornis heeftindien het 1 stellid van de tweeling een paniekstoomis heeft, aanzienlijk groter indien het een eenelige in plaats van een twee-elige tweeling betreft. Er zijn een serie aanwilzingen dat het noradrenerge systeem bil paniekpatienten hyperreactief is: clonidine reduceert de centrale noradrenerge transmissie en heeft in panlekpatlénten een sterker hypotenslef effect dan in controle proefpersonen. Omgekeerd reageren paniekpatienten heftlger op farmacologische stimulering van het NA systeem mild dels b.v. Yohimbine. Interessant genoeg vonden will recent dat gezonde studenten metde beste wil van de wereld niet konden uitmaken of ze een placebo hadden gesllkt of $20 \mathrm{mg}$ Yohimbine. Meer dan $90 \%$ van de panlekpatienten wist dat binnen 30 minuten met zekerheld te zeggen. Ook farmacotherapeutische bewindingensteunenhetidee datpanlekpatinten in blologlsch opzicht afwliken van controles. Zo zijn tricyclische antdepressiva, die direct of indirect inwerken op het NA, systeem, vili effectief bli de behandellng van panlek. Zeer gunstige effecten worden bereikt met de getriazoleerde benzodiapine Alprazolam. Slechts terzijde zil gemeld dat de nevenwerkingen diarvan mill nogal ernstig voorkomen. Dit voor wat betreft biologische perspectieven op paniek.

Varuit gedragswetenschappelike kring is op hel wolgende gewezen. Panlekpatiénten rapporteren dat tildens 
paniekaanvallen diverse saillante lichamelikke gevoelens worden waargenomenen. meer nog patienten zeggen bang te zijn voor die lichamelijke symptomen. Er is geopperd door gedragswetenschappers, dat lichamelijke gevoelens mér zijndaneplitenomenen. Panlekpatlentenzoudeneen foblsche angst kunnen hebben woor specifieke lichamelljke gevoelens: wadrneming van en specifleke sensatie zou lelden tot subjectieve angst en tot versterking van de optredende vreeswekkende llchamelijke gevoelens. Hoewel deze theorie nogal grof is geschetst kan lets worden gezegd over de empirische kredietwaardigheld. Allereerst werd zonneklaar dat inderdaad paniekpatienten zeer speciflek interoceptieve angsten hebben. lets preclezer, panlekpatlënteninterpreteren lichamelijke signalen als voorbodes van catastrofes, zoals een hartaarval. Het aanbleden van de gevreesde llchamelijke gevoelens, b.v. door isoproteronol, caffeïne, natrium lactaat, CO2. Yohimbine etc. Neldt in panlekpatienten tot angst; in controle proefpersonen niet of nauwelijks. Dat strookt zeer nauwkeurig met een psycholagische "interoceptlieve angsttheorle". Paniekpatlënten dle vór $\mathrm{CO} 2$ Inhalatie goed worden geînformeerd zjinnauwelljks meer bang. Inzeer elegant onderzoek werd nep feedback (auditlef) gegeven van een hartslagacceleratie aan "normalen"enaanpaniekpatiënten. In "normalen" leiden de vermeende hartslagacceleratie niet tot angst en to een (lichte) daling van de feltelike hartslag frequentie. In paniekpatienten daarentegen trad nlet alleen angst op, doch ook een stijging van de feltelijke hartslag en bloeddruk. Eenlaatste bevinding van enige klinische relevantie Is de behandellng met cognitleve therapie. De resultaten die gepubllceerd zlinn lljken zeer goed.

Tot zover de casus "panlekonderzoek". Casuistische 
mededelingen bewijzen niets doch hebben een heurlistische waarde. Wat suggereert de huidige casus? In de eerste plaats valt op dat zowel gedragswetenschappelijk- als blomedisch geörienteerde onderzoekers zlch tegen hetzelfde fenomeen aanbemoelen. Het paniekonderzoek geeft voorbeelden van biomedische theorieen die leld den totkrachtige voorspellingen die uitkwamen en die niet gaed gedragswetenschappelik te verklaren zijn (ik denk b.v. aan het herkennen van Yohimbine door patiënten en nlet door gezonde proefpersonen). Tevens echter zijngedragswetenschappelijke bevindingengenoemd dle nletéén, twee, drile totblomedische premlssen te herlelden zljn. (Er zj) b.v. terugverwezen naar de eerder genoemde bevinding datauditlevenep feedback van hartslagacceleratie vreeswekkend is voor panlekpatlënten maar nletvoor controle proefpersonen). Dater gedragselgenaardigheden zlin die well met biologische -, en niet met psychologische premissen te verklaren ziln is nlets nieuws: te denken valt aan gedragsabberaties ten gevalge van hersentrauma's. Maar hoe zit dat omgekeerd: zijner gedragingen die zich wilsslultend in psychologlsche-, en niet in blologische termen laten verklaren? Het komt mil voor van niet. Ik kan mij geen gedrag of bewustzjnstoestand vaorstellen zonder neuronale basis. Zouden will die basis kennen dan zouden we het gedrag kunnen verklaren en voorspellen. Zouden we de neuronale toestand creëren dan zou het gedrag optreden. Bil implicatie meen ik derlhalve dat aan biljzonder gedrag een bijzonder biologisch substraat ten grondslag ligt. Ook al huldigt men. zoals de huidige spreker, zo'n enigszins reductionistisch standpunt, dan impliceert dat echter geenszins dat biopsychiatrisch experimenteren vruchtbaarder zal zilin don gedragswetenschappelijk onderzoek. Dit kan verduidelijkt 
worden met een vaorbeeld dat ik dankbaar ontleen aan de Britse filosoof Dennett.

Schaakcomputers zijn ingewikkelde machines. Ontwerpers van hardware en software voor schackcomputers weten zeer wel dat elke voligende ze t van het apparaat valledig bepaald wordt door de fysieke toestand van de computer. Wie wil winnen van de computer, zal hetgedrag van het ding moeten voorspellen. Zo"n op winnen en voorspellen beluste speler doet er onverstandig aan de momentane fysieke toestand van de machine in zifn overwegingen te betrekken. Dat is onverstandig omdat het apparaat daarvoor veel en veel te complex Is. Nee, mensen die willen winnen van een goede schaakcomputer, en dat geldt ook voor computertechnicl. dle maken slechts een kans indlen zil can de computer bedoelingen en redeneringen toedichten. De computer "wil" winnen, hll "probeert" mil om de tuin te lelden, hil "denkt" dat ik hem niet in de gaten heb, etc. De moraal van dit voorbeeld is het volgende: of men gedrag wenst te verklaren in psychologische of in fyslische termen hangt er niet vanaf of gedrag uteindelijk een neurochemische basis heeft. Een pragmatisch standpunt lijkt produktiever: vanult welk perspectlerkomen we to tde meest interessante voorspellingen en tot dekrachtigste manlpulaties? Het is zekernletop voorhand duldelljk dat fysische perspectieven het meest vruchtbaar zj): dat geldt voar complexe schaakcomputers en dat geldt a fortion voor normaal en abnomaal gedrag waarvan de bedrading nog zo ontzagwekkend veel complexer is.

Experimenteel psychopathologisch onderzoek wordt echt spannend wanneer blologische en psychologische perspectleven rechtstreeks vergeleken worden met betrekking tot hun voorspellende kracht. Vaak betreft dat laboratorlum 
onderzoek; soms is de inzet van zo'n krachtmeting de therapeutische effectenvan ingrepen. Een fraal voorbeeld wan dat laatste is een recente studle van Klosko et al. (1988) waarin de anti-paniek effecten werden vergeleken van wat de krachtigste farmacologische, respectievellik psychologische strategleên lijken te zijn: Alprazolam respectievelijk cognitieve therapie. Wat help thet beste? Deze strijd werd beslecht in het voordeel van de cognitieve theraple: $87 \%$ van de patienten vrij van paniek metcognitieve theraple vs $50 \%$ met Alprazolam. Eén studle is te weinig voor deflnitieve conclusles. Nieuw klinisch onderzoek wordt met spanning afgewacht.

De casus paniekonderoek maakt nog lets duidelijk. Zowel het biologische als het gedragswetenschappelljk onderzoek heeft belangrlike klinische en maatschappelijke Implicaties. De gevondentoepassingsmogelijkhedenkonden duldelijk worden doordat voorheen uitvoerig onderzoek werd verricht naar fundamentele, pre klinische kwesties. Onderzoekers op het terrein van de bilologische psychiatrle en de leertheorle/ cognitieve psychologle hébben lets om toe te passen. De oproep aan universitaire onderzoekers om toch wooral toepasbaar klinisch relevant onderzoek te doen is luid en natuurlijk moet zulk onderzoek ook gebeuren. Ik hecht eraan te waarschumen tegen een premature, al te eenzildige orlêntatle op toegepast onderzoek gericht op de oplossing van branclende maatschappelike kwesties. We weten nogzo weinlg. Laatons de tild nemenom kennis - mogellik toepasbaar - te verwerven.

Met deze korte excursie naar het angstonderzoek trachtte ik allereerst te laten zlen dat gecombineerd blologisch / psychologisch onderzoek belangrilk. spannend en leuk is. Tevens moge het angstonderzoek en voorbeeld hebben 
gegeven van maatschappellik en klinisch relevante. toepasbare inzichten die pas konden ontstaan door een gerume Investering in fundamenteel psychologisch en farmacologisch onderzoek. Duidelijk werd dat onderzoekers soms opbotsen tegen het lichaam/geest probleem of zo U wilt. het llchaam/geest mysterie. Met verwijzing naar Dennetts' schaakcomputer werd betoogd dat een pragmatische opstelling hier vruchtbaar is.

De thema's waaraan $k$ tot slot enige besplegellngen wil wijden zijn de maatschappelike relevantle van Geestelijke Gezondheldkunde, het onderwils in de Geestelijke Gezondhelakunde en de relatle van Geestelljke Gezondheidkunde met andere disciplines. Wat eerder werd gezegd over het object en het onderzoek van de Geestelijke Gezondheldkunde heeft evidente implicaties voor de maatschappellik relevantie van het vak, de aard van het onderwiljs en de relatle met andere disciplines. Ik kan lets minder lang van stof worden.

Dames en heren, de voorafgaande besplegelingen waren wellicht wat abstract. Misschien ontstond de indruk dat Geestelijke Gezondheldkunde gaat over lets dat ververwijderd is van gewone mensen. Als die indruk werd gewekt is dat ten onrechte. Dit zil verduidellkkt met enlge gegevens. Sǘclde behoort, nlet alleen onder psychiatrische patienten maar ook onder de jongere bevolking, tot één van de belangrilkste doodsooraken. Per Jarar doen ongeveer 100.000 iandgenoteneen poging: ruim 2.000 beneemt zichzelf daadwerkellik het leven: In Nederland kregen twee jaar terug, zo'n 600.000 mensen een uitkering ap grond van volledige arbeldsongeschiktheld. Zo'n 160,000 daarvankrigen hun uitke- 
ring wegens een "psychlsche. zlekte". Daamee vormt "psychische ziekte" veruit de grootste van de 17 door de Gemeenschappelijke Medische Diensten (GMD's) onderschelden dlagnostische groepen op basis waarvan tot arbelidsongeschiktheid wordt besloten. De één na grootste diagnostische groep zijn de aandoeningen aan het bewegingsapparaat. Het leeuwedeel van de uitkeringen hler wordt uitgekeerd in verband met "psychosomatische (rug)plin". dat is plin wcarvoor geen anatomisch substraat aanwezlg is. Met het betalen van uitkeringen aan rugplinpatiënten is zeer veel geld gemoeld. Vanaf het moment dat de dekaan mil het woord gaf tot nu, kostte, "psychosomatische", lage rugpllin alleen al de gemeenschap zo'n half miljoen gulden. Psychische ellende, gestoord gedrag gaat ons aan, al was het maar als bellastingbetaler.

Deverlening van hulpaanmensen metpsychische problemen theeft zich in Nederland verzelfstandigd. Dat begon tussen de beide wereldoorlogen met de instelling van de Sociaal Psychlatrische Diensten, de Medisch Opvoedkundige Buro's en de Buro's voor Levens-en Gezinsvragen. Met de instellingen van psychotherapeutische instituten vlak na de tweede wereldooriog heeft die ontwikkeling doorgezet. De integratie van de vele woorzleningenheeft geculmineerd in de oprlchting van de Regionale Instituten voor Geestellike Gezondheldszorg. de RIAGG's. Het werk in de geestelijke gezondheldszorg waarvoor een hogere opleiding nodlg wordt geacht, wordt vooral verricht door psychiaters, psychologen, pedagogen, maatschappelijk werkers en soclaal psychlatrisch verpleegkundigen. Belangwekkend is de forse overlap dle er is tussen de activitelten die door vertegenwoordigers van verschillende disciplines worden verricht. Als nief wordt gelet 
op inschaling of formele taakomschrivingen. doch als men zlch beperkt fot de feltelijke professionele werkzarnheden zal niet ontgaan dat er vervaging is opgetreden van de grenzen tussen de disciplines. De oorspronkelike rolverdeling naar professie. blivoorbeeld van de psychiater als medicus en de psycholoog ais testdeskundige, betekent nog maar weinig in hun huldige dagelijkse werkzaamheden. Beiden zijn nu diagnostisch en therapeutisch werkzaam op het hele gebied van gedragsproblemen in de geestellike gezondhelidszorg.

oak het wetenschappelijk onderzoek laat een dergelijke branche-vervaging zlen. Onder de meest gerenommeerde leertheoreticl en gedragstherapeuten bevinden zlich nogal wat medicl. Belangrijk blologisch-psychlatrisch werk woralt verricht door psychologen.

Genoemdeverzelfstandiging envervaging vangrenzen tussen professles suggereert de levensvatbaarheid van een elgensoortige universitalre studle. Dit is overlgens geen nleuwe gedachte. Zo pleitte Baan in de zestiger jaren al voor een ontkoppeling van de opleiding tot psychlatervan de algemeen geneeskundige studie.

De situatie in de geestelijke gezondheldszorg is op een aantal punten vergellikbaar met het onderwljsbeleld en het bedriffsleven. Ook daar waren van oudsher academlci werkzaam met sterk onderschelden opleidingen die nief duidelitk gerelateerd waren aan feltelike activiteiten. Er ontstonden hier veldwetenschappen: onderwilskunde en bedrljfskunde. Kenmerkend voor zulke veldwetenschappen is dat niet én disclplinalr perspectlef (b.v. onderwijspsychologie of bedrlffeconomie) het ordenend princlpe vormt. Het object van het vak wordt gedefinieerd door een groep samenhangende problemen. Heł ziln de problemen die de 
samenhang en organisatie bepalen: niet bepaalde aspecten zoals psychologische, economische of juridische. Wat gold voor onderwijskunde en bedrijfskunde. geldt voor Geestellike Gezondheidkunde. Het is een veldwetenschap van de geestelijke gezondheidszorg. Studenten bestuderen de problemen dle de bestaansgrond vormen van de geestelijke gezondheidszorg: angsten, wanen, depressles, verslaving etc. Zoals voorgaande suggereerde is Geestelljke Gezondheldkunde geen welzijnswetenschap doch vornt het een academische studie met gedragsproblemen als object. De oplelding in de Geestelijke Gezondheidkunde is multidisciplinair. Als goede vuistregel geldt dat ongeveer $1 / 3$ van de disclplinaire $\|$ breng afkomstig is uit de bilo-medische wetenschappen, ongeveer 1/3 uit de gedragswetenschappen en ongeveer $1 / 3$ uit de soclo-culturele wetenschappen. Tijdens de studle verdleptmenzjch in o.m. de klinlsche fenomenologle. diagnostiek, epidemiologie, etiologie en behandeling van gedragistoornissen. Hoewel de oplelding goeddeels besta uit het verwerven van kennis, wordt rulme aandacht besteed aan het verwerven van praktische vaardigheden. Afgestudeerden wéten nlet alleen wat, ze kúnnen ook wat. Studenten zljn voorbereld op een beroepsultoefening in de geestelijke gezondheidszorg. Ze kunnen aldaar als Junior medewerker bildragen aan o.m. begelelding. behandeling. diagnostiek, preventie, evaluatie, onderzoek en programmaontwikkeling. Afgestudeerden die klezen voor werken in de patientenzorg zullen, evenals andere academicl, naar verwachting een eerste periode als junlor functioneren en onder supervisie staan van bijvoorbeeld een psycholoog of psychiater. Eenenander zal kunnengebeuren blj bllvoorbeeld RIAGG's en in psychiatrische zlekenhuizen. Een alantal 
studenten zal werkzaam kunnen zijn in meer fundamenteel onderzoek. Wat de kansen op werk zjin, vergeleken met afgestudeerden in andere richtingen van deze faculteit of vergeleken met afgestudeerden met verwante opleidingen. dat weten we nog niet: er ziln slechts enkele studenten afgestudeerd. De beste bijdrage dle de wetenschappelijke staf alhier kan leveren is het aanbieden van een ultmuntend curriculum.

Wanneer het veldwetenschappelijk karakter van Geestelijke Gezondheldkunde voor ogen wordt gehouden, is de relatie met andere vakgebleden kort en eenvoudig te verhelderen. Studenten worden nlet opgeleid in één discipline om deze dan in een latere fase van de studie, tijdens een specialisatie. toe te passen op een bepaald gebled. Studenten bestuderen problemen en maken daarbil dankbaar gebruik van het intellectuele erfgoed van eerdere generaties en van andere dlsciplines. Soms is datleertheorie, soms de klinische psychlatrle. soms epldemlologie, soms psychofysiologie, etc, Geestelijke Gezondheidkunde is dus geen klinische psychologle en ook geen verkapte klinische psychalogie, zoals wel eens is geopperd. Natuurlijk wordt geprofiteerd van veel von het goede dat de psychologie te bleden heeff; hetzou dom ziln dat nlet te daen. De verhouding van de opleiding Geestellike Gezondheidkunde tot de opleiding (klinische) psychologle is echternlet anders dan de verhouding tussen bedrlifskundeen. pak weg. bedrifseconomie.

Wil zjn gekomen aan het einde van deze les. Ik heb getracht In grove, men mag wel zeggen, in zér grove lijnen te schetsen wat het object is van Geestelijke Gezondheidkunde, waarom dat zo is, aan wat voor soort onderzoek de Geestelijke 
Gezondheidkunde een bijdrage kan leveren. wat de maatschappelijke relevantie ervan is, hoe het onderwijs eruit ziet.c.q.zou moetenzienen hoe Geestelike Gezondheldkunde gesitueerd is ten opzichte van verwante empirische wetenschappen.

Dames en heren studenten.

Een nieuwe afstudeerrichting als de onze heeft slechts recht van bestaan indien de opleiding zeer goed is. De opleldingsfacilitelten waarover U in betrekkelijke vrijheld kunt beschikken. lijken me voortreffelijk, doch daarmee is lang niet alles gezegd. De kwalliteit van een oplelding immers is vooral afhankelijk van de inzeten werklustvan de betrokkenen. Welnu, lk bengetroffen door Uw weetgierigheid, enthousiasme en de kundigheid van degene van U die inmiddels afstudeerden. Natuurlijk worden de mogelijkheden van universitaire vorming begrensd door de beperkte studieduur die ons lls toegestaan. Binnen die beperking, die ook voor andere opleidingen geldt, is er gegronde reden to optimisme en zelfvertrouwen. Een aantal Uwer geeft blijk van ware wetenschappelijke hartstocht en participeert in universitair onderzoek. Uw intelligentle. Uw onbevangenheld en vaak UW bevlogenheld maakt intenslef contact vruchtbaar en uiterst aangenaam. Ik hoop van U te blijwen leren.

Dames en heren, leden van het College van Bestuur.

De voordracht voor de huidige leerstoel is een van de eerste die niet werd bekrachtigd door de Kroon doch door U. Ik ben aan $U$ niet minder dank verschuldigd dan dat ik aan de 
Koninglin geweest zou Zin. Naar beste kunnen zal ik frachten het vertrouwen door $U$ gesteld in mil en in de wijsheld van de voordracht door de Faculteit der Gezondheidswetenschappen niet te beschamen.

Dames en heren, leden van de vakgroep Geestellke Gezondheidkunde.

U vormt een weinig bureaucratisch, om nlet te zeggen een anarchistisch zootje ongeregeld. Het is enkel dankzi] Uw piratenopiredendat het curriculum Geestelijke Gezondheldkunde zo sprankelend en goed werden dat hetop tijd klaar was. Voor dit wapenfelt verdient $U$ groot respect. Nu het curriculum. aithans een eerste versle ervan, af is en de hete adem van nleuwe jaargangen studenten niet meer in de nek gevoeld wordt, nu is de tijd daar onze "splendid isolation" enlgszins te verbreken en om geregeld overleg te voeren met de facultelt waarvan Geestelijke Gezondheldkunde deel uitmaakt.

Dames en heren, leden van het onderzoekprogramma Experimentele Psychopathalogie.

Binnen enkele jaren is een clubje in research geinteresseerde gedragstherapeuten ultgegroeld to thell huldige Experimentele Psychopathologie. waar interdisciplinali, interfacultair onderzoek word verticht; onderzoek dat deels fundamenteel. deels toegepast is en dat een deels leertheoretische, deels cognitilef psychologische, deels psychofysiologlsche en deels blologlsch psychlatrische signatuur heeft.

vooral door de nletaflatende stroom voortreffelljke publicatles 
die U liet verschilnen, heeft Experimentele Psychopathologie een vooraanstaande internationale positile verwowen. Binnen zo'n productieve groep te werken is stimulerend en plezierig. Niet alleen is veel goed werk verzet, er zijn goede gronden te geloven dat het beste nog moet komen.

Het is een voorrecht leiding te mogen gevenaan een dergelijk team.

Hooggeleerde Bremer, zeer geleerde Beekers, beste Joosten beste Max.

Julle stonden aan de wleg van Geestelijke Gezondheidkunde en Max. jij initleserde bovendien het onderzoekprogramma "Experimentele Psychopathologle". Het tot ontwikkeling brengen van een nieuwe afstudeerrichting en een nleuw onderzaekprogramma verelsen visle, daadkrachten bestuurlijk uithoudingsvermogen. Zonder dat was Experimentele Psychopathologle er nletgeweest, was Geestelike Gezondheldkunde er nlet geweest en waren wil hler nu niet verenigd. Jullie beiden, weet je verzekerd van mijn erkentelijkheld.

Domes en heren overige alanwezlgen.

Ook $U$ ben lk erkentelijk: voor de belangstelling waarvan $U$ door Uwaanwezlgheld blik gaf en voor hetonderdrukken van openlijke tekenen van de vervellng die U ongetwl|feld tildens deze oratie is overvallen. Laat ons dit samenzijn in Informele sfeer voortzetten in het Trefcentrum. Me dunkt dat niemand 
ermere gebaat is indien Uhet Trefcentrum in slagordeopstelling betreedt. Laat ons hef glas heffen doch wacht U daarmee niet tot will elkander de hand hebben geschud.

In het valle besef van miln fellbaarheid beëindig ik deze les.

Itc hab gezegd. 